\title{
Recent changes in the Wanda Glacier, King George Island, Antarctica
}

\author{
Kátia Kellem da ROSA ${ }^{1}$, Rosemary VIEIRA², Guilherme FERNANDEZ ${ }^{3}$, Claudio Wilson MENDES \\ Jr. $^{1}$, Luiz Felipe VELHO ${ }^{1}$ \& Jefferson Cardia SIMÕES ${ }^{1}$
}

\begin{abstract}
${ }^{1}$ Centro Polar e Climático, Universidade Federal do Rio Grande do Sul. Av. Bento Gonçalves, 9500, CEP 91.540-000, Porto Alegre, RS, Brasil. E-mail: katia.rosa@ufrgs.br, jefferson.simoes@ufrgs.br, lfvelho@gmail.com, geoclaudio@yahoo.com.br.

${ }^{2}$ Laboratório de Processos Sedimentares e Ambientais, Instituto de Geociências, Departamento de Geografia, Universidade Federal, Fluminense. Av. Gal. Milton Tavares de Souza, s/n, Campus da Praia Vermelha, Boa Viagem, CEP 24210-346, Niterói, RJ, Brasil. E-mail: rosemaryvieira@id.uff.br.

${ }^{3}$ Instituto de Geociências, Laboratório de Geografia Física, Universidade Federal Fluminense. Av. Litorânea s/n, Campus Praia Vermelha, Niterói, RJ, Brasil. E-mail: guilhermefernandez@id.uff.br.
\end{abstract}

Nova submissão recebida em 01/2015. Aceito para publicação em 08/2015. Versão online publicada em 19/08/2015 (www.pesquisasemgeociencias.ufrgs.br)

\begin{abstract}
Recent glaciological changes in Wanda Glacier, King George Island (KGI), South Shetland Islands $\left(61^{\circ} 54^{\prime} \mathrm{S}\right.$ and $62^{\circ} 16^{\prime} \mathrm{S}, 57^{\circ} 35^{\prime} \mathrm{W}$ and $\left.59^{\circ} 02^{\prime} \mathrm{W}\right)$ off the Antarctic Peninsula, were quantified by ice flow velocity, direction and fluctuation of glacier termini measurements. Topographic changes and DGPS surveys as well as transverse and longitudinal profiles were carried out to generate a Digital Surface Model. Results show that Wanda Glacier has a small drainage basin, a high retreat rate through fusion processes and reduced ice thickness if compared to other glaciers in KGI. Surface-area changes are assessed using historical satellite imagery from 1979 to 2011. Wanda glacier lost about $31 \%$ of its original $\left(1.5 \mathrm{~km}^{2}\right.$ of area in 1979). The current continuous and fast retreat phase is attributed to the recent regional warming. Maximum ice surface velocity, measured using a stake network, reached $2.2 \mathrm{~cm} \mathrm{~d}^{-1}$ during the period of 2007-2011. Transverse profiles show the influence of the topography on the ice flow. Due to its small size and thermal conditions, Wanda Glacier responds rapidly to climatic variations, revealing its relevance for environmental studies. Keywords: glacier monitoring, climatic changes, glaciology, remote sensing.
\end{abstract}

Resumo - Mudanças Recentes na GEleira WANDA, IlHa Rei George, AntáRtica. Mudanças glaciológicas recentes na geleira Wanda, Ilha Rei George, Shetlands do Sul (latitudes $61^{\circ} 54^{\prime} \mathrm{S}$ a $62^{\circ} 16^{\prime} \mathrm{S}$ e longitudes $57^{\circ} 35^{\prime} \mathrm{W}$ a $59^{\circ} 02^{\prime} \mathrm{W}$ ), fora da Península Antártica, foram quantificadas através de medidas da direção e velocidade do fluxo de gelo e das flutuações em sua posição frontal. Dados topográficos e medidas de DGPS, bem como perfis transversais e longitudinais para a geleira foram obtidos para a geração de um Modelo Digital de Superfície. Os resultados demonstram que a geleira Wanda possui uma pequena bacia de drenagem, um alto grau de retração através de processos de fusão, e reduzida espessura se comparada com outras massas de gelo da Ilha Rei George. Mudanças em sua área foram obtidas pela utilização de imagens de satélite multitemporais do período de 1979 a 2011. A geleira Wanda perdeu aproximadamente $31 \%$ de sua área original desde $1979\left(1,5 \mathrm{~km}^{2} \mathrm{de}\right.$ área em 1979). Atualmente, apresenta uma contínua e rápida fase de retração, atribuída ao recente aquecimento regional. A velocidade superficial máxima do fluxo de gelo, medida através de uma rede de estacas implantadas na geleira, foi estimada em 2,2-1 $\mathrm{cm} /$ dia durante o período de 2007 a 2011. Perfis transversais mostraram a influência da topografia na direção do fluxo de gelo. Devido à sua pequena área apresentada e sua condição termal, a geleira Wanda responde rapidamente às variações climáticas, revelando relevância em estudos ambientais.

Palavras chave: monitoramento glacial, mudanças climáticas, glaciologia, sensoriamento remoto.

\section{Introduction}

Glaciers are sensitive indicators of climatic changes and play an important role in regional climates (Hope et al., 1998). They are components in albedo feedback mechanisms of the climate system and their low temperature contribute to the global temperature gradient (Pellikka \& Rees, 2010).

Glacier velocities and their surface topography are important parameters to monitor glacier volume and mass balance (Pellikka \& Rees, 2010). Therefore, glacier area variation, ice flow velocity 
and glacier frontal position monitoring could be used to model accurately the response of glaciers to regional climate variability.

This paper investigates recent glacial changes in Wanda Glacier, King George Island, Antarctica. This work provides quantitative datasets that can be used to measure rates at which such changes are taking place. Multitemporal satellite images data were used to monitor the glacier. Topographical and DGPS surveys were carried out during two fieldworks, in order to generate a Digital Elevation Model (DEM) and transverse and longitudinal profiles, and to estimate superficial ice flow directions and velocities of the Wanda Glacier.

\section{Area, material and methods}

\subsection{Area}

Wanda Glacier is located in King George Island ( $61^{\circ} 54^{\prime} \mathrm{S}$ and $62^{\circ} 16^{\prime} \mathrm{S}, 57^{\circ} 35^{\prime} \mathrm{W}$ and $59^{\circ} 02^{\prime} \mathrm{W}$ ), South Shetland Islands, off the Antarctic Peninsula (Fig. 1). This glacier has a proglacial front characterized by several landforms and proglacial deposits, as a consequence of its recent retreat.

The Antarctic Peninsula region (AP) had one of the most intense climatic warming trends over the last decades (IPCC, 2007). According to Turner et al. (2005), there was an increase in air temperature of approximately $0.56^{\circ} \mathrm{C}$ per decade in the western AP (Faraday/Vernadsky weather station; $65^{\circ} 15^{\prime} \mathrm{S}$ and $64^{\circ} 16^{\prime} \mathrm{W}$ ). The AP annual surface air temperature has increased about $3^{\circ} \mathrm{C}$ since 1950 (Monaghan et al., 2008).

Several studies have provided evidences of glacier retreats in the Martel Inlet (Fig. 1) since 1956 (Simões \& Bremer, 1995; Park et al., 1998; Bremer, 1998; Simões et al., 1999; Aquino, 1999; Braun \& Goßmann, 2002; Vieira et al., 2005; Rosa, 2008; Rosa et al., 2009).

Over the past 30 years, the number of days with liquid precipitation and positive air temperatures has been rising in summer. These processes accelerated the snowmelt and increased the negative mass balance of local glaciers (Braun et al., 2001; Ferrando et al., 2009). The South Shetlands ice masses are highly sensitive to environmental changes due their geographical position (between $61^{\circ} 04^{\prime}$ and $63^{\circ} 20^{\prime} \mathrm{S}, 54^{\circ} 00^{\prime}$ and $62^{\circ} 25^{\prime} \mathrm{W}$ ), their small area, and because the glacier ice is near or at the pressure melting point (Macheret et al., 1997; Pfender, 1999; Arigony-Neto et al., 2001; Simões et al., 2004). Their retreat processes are linked to the regional atmospheric warming observed over the last decades (Park et al., 1998; Simões et al., 2004; Cook et al., 2005; Blindow et al., 2010).

\subsection{Material and methods}

We used SPOT imagery (acquired on February, 1988 and on March, 1995 and 2000), QUICKBIRD (2006) and COSMO-SKYMED (February, 2011) imagery to quantify recent area changes in the Wanda Glacier. All data were projected in Universal Transverse Mercator (UTM), zone 21, World Geodetic System 1984 (WGS84).

Flutings deposits were identified in the proglacial area to determine the recent glacier ice flow directions. These deposits have an elongated form aligned parallel to the ice flow direction and also indicate basal melt rates (Bennett \& Glasser, 1996).

The glacier motion was surveyed by putting stakes on the glacier during fieldwork activities on December, 2007 (Fig. 2 and 3), according to techniques of Anderson et al. (2004) and Macgregor et al. (2005).

The stake positions over a period were measuring with accurate Differential Global Positioning Systems (DGPS). These data were post-processed for differential correction in EZSurv software (VIASAT Geotechnologies, Inc.). The coordinate points were corrected in relation to a base station, which consisted of a GPS antenna (62 $04^{\circ} 58^{\prime \prime} S$ and $58^{\circ} 23^{\prime} 39^{\prime \prime} W$; altitude of $57.53 \mathrm{~m}$ ) installed near the Brazilian Comandante Ferraz Antarctic Station (EACF). This antenna is part of the Brazilian Network of Continuous Monitoring (RBMC) GPS System, managed by the Brazilian Institute of Geography and Statistics (IBGE). We carried out another DGPS survey of the same stakes on summer of the 2007 and 2011. Ice flow direction and velocity were determined based on the stakes position in these two years.

Glacier orthometric altitudes were obtained by a trigonometric survey carried out on January, 2001, with a total station model Topcon (1993) (Leica Geosystems). We determinated other planialtimetric points by DGPS surveys, using a topographic receiver (model GTRA). Corseuil \& Robaina (2003) demonstrated the possibility of using GPS for altimetric surveys, if these data are corrected by a geoid undulation model. The planialtimetric coordinate points were determined by rapid static and kinematic surveys, using reference data from the EACF GPS antenna. GPS ellipsoidal altimetric coordinate points were transformed to orthometric altitudes, referenced to World Geodetic System (WGS 84), by using the geoid undulation model 


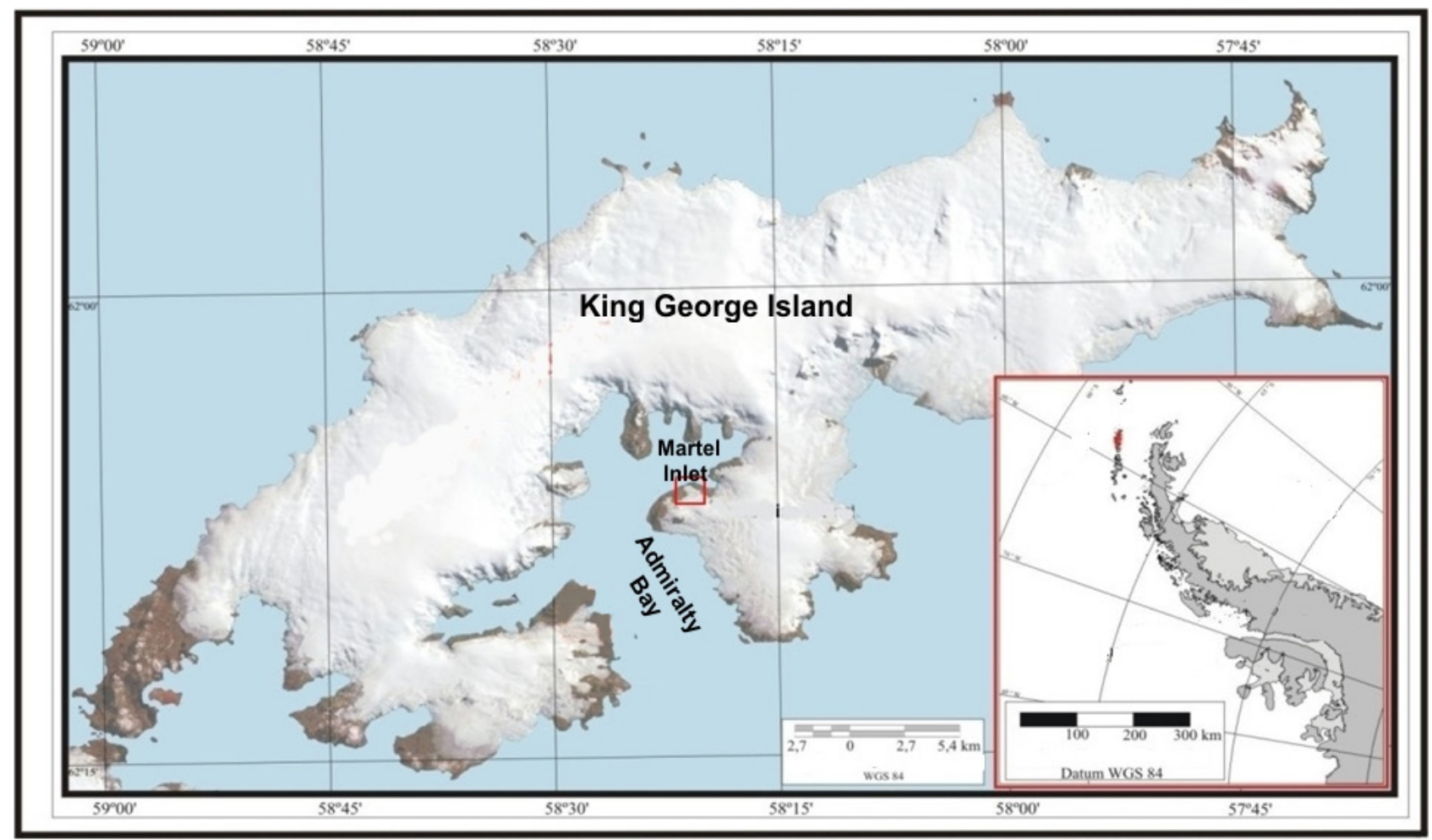

Figure 1. Wanda glacier location in King George Island, South Shetlands archipelago.
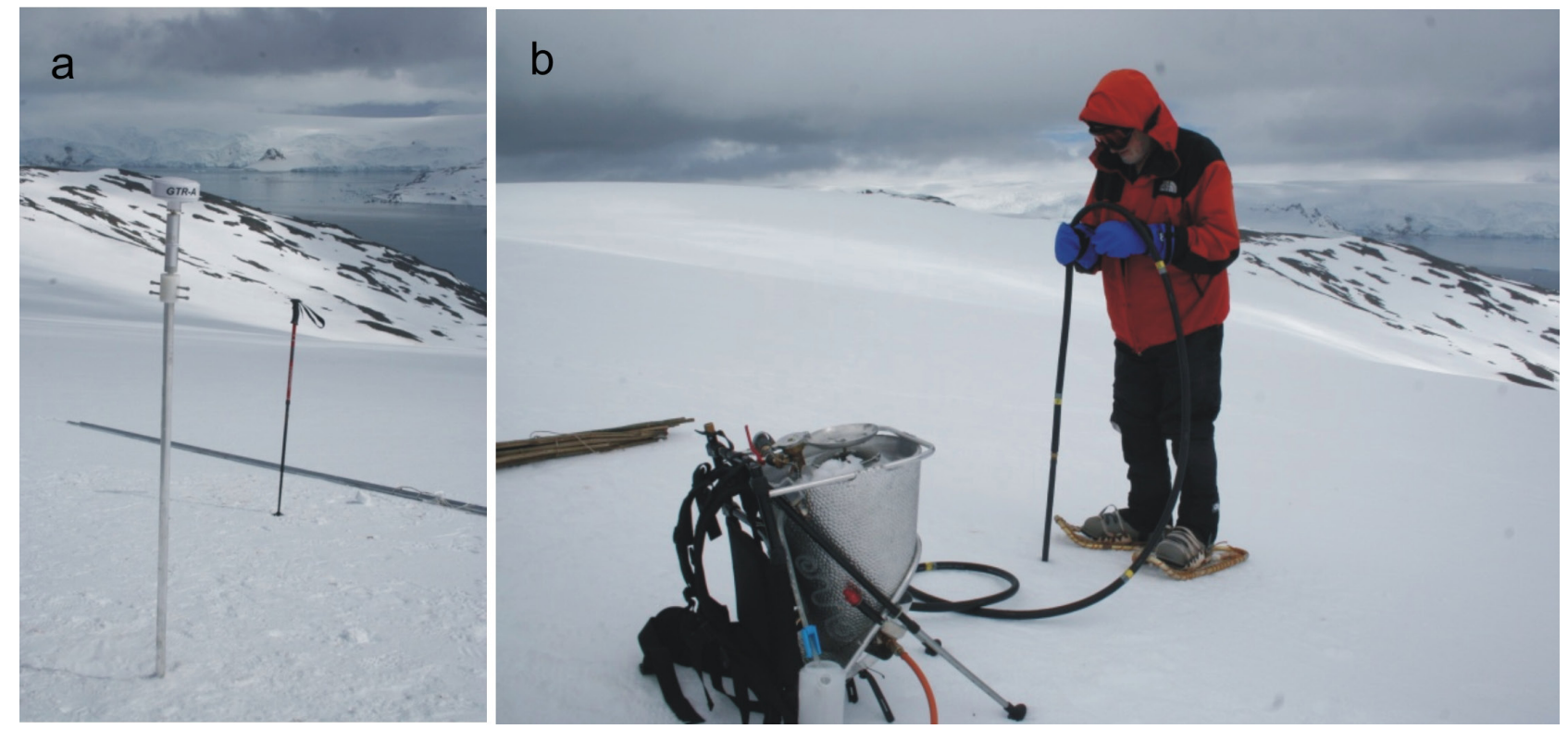

Figure 2. GPS antenna coupled to one stake (A) fixed into the Wanda glacier centerline. Each $3 \mathrm{~m}$ aluminum stake was fixed in a hole of $2 \mathrm{~m}$ depth, dug by a thermal ice drill (B).

EGM86 (Earth Gravity Model 1996), based on the procedure described by Hofmann-Wellenhof et al. (1997). These orthometric data were then interpolated using the SURFER software (Golden Software, Inc.) to generate a glacier DEM. The Ordinary Kriging interpolation method was applied for better representation of the glacier smooth surface morphology.

\section{Results}

\subsection{Wanda Glacier retreat rate}

The glacier drainage basin area, estimated using the orthorectified COSMO-SKYMED imagery acquired on February (2011) is about 1.56 $\mathrm{km}^{2}$. Fig. 4 shows the changes in Wanda Glacier 
terminus position from 1979 to 2011 , with details provided in Tab. 1. In 1979, the glacier was characterized by tidewater terminus (Fig. 4 and 5). Since those years the glacier has receded by an average of $22 \mathrm{~m} \mathrm{a}^{-1}$.

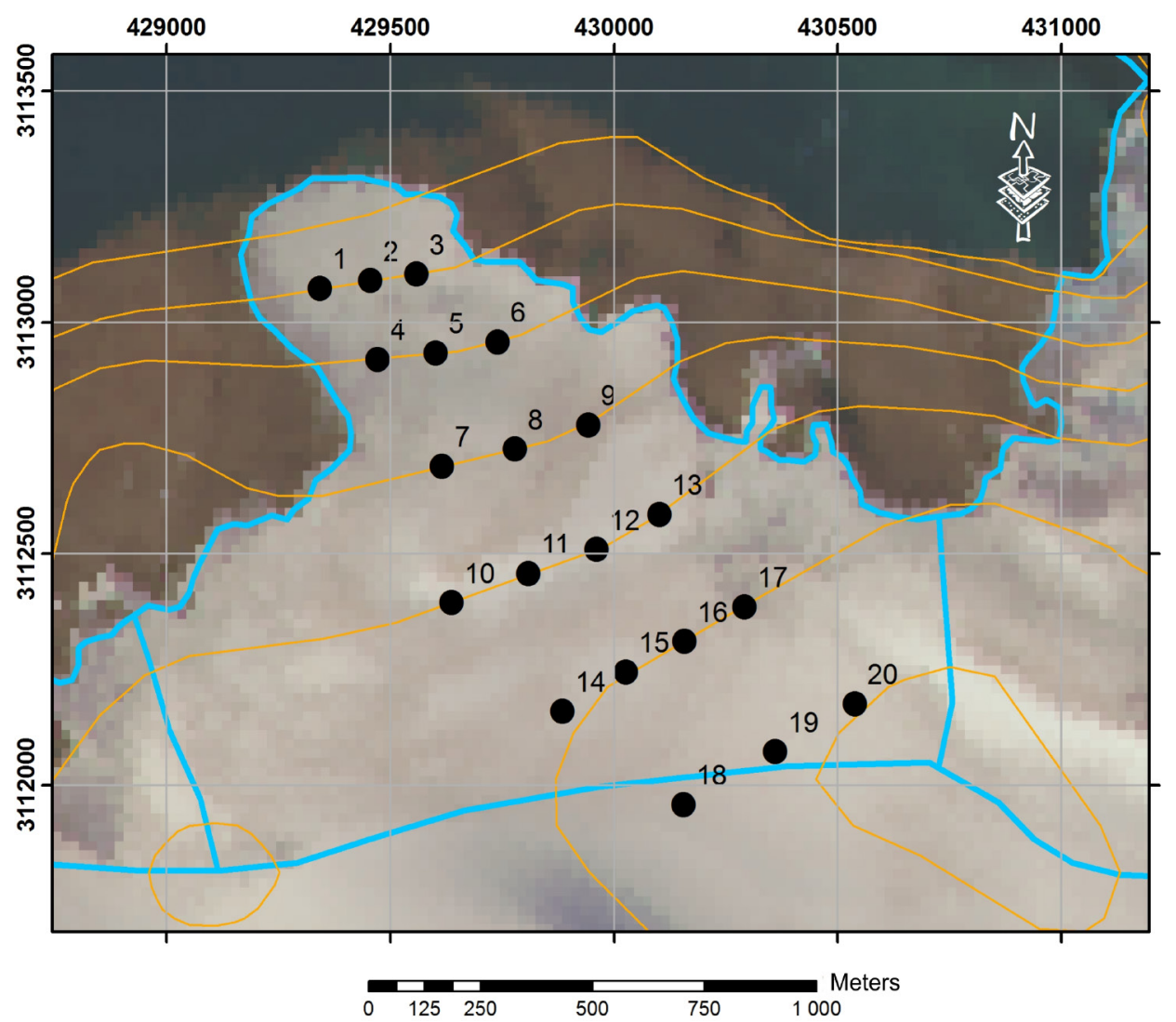

Figure 3. Stakes location along the Wanda Glacier surface. The glacier drainage basin boundaries are delimited by Bremer (1998), and overlapping a SPOT image (2000).

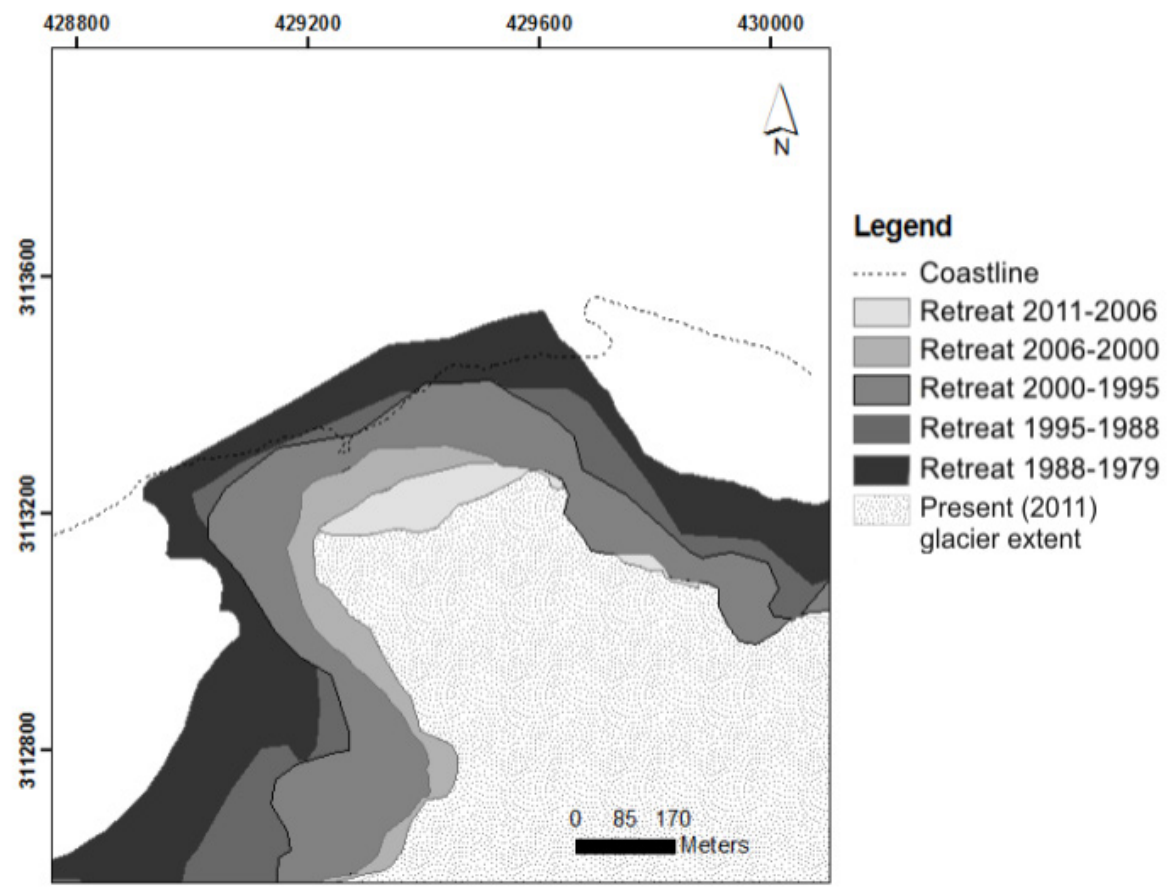

Figure 4. Wanda glacier map showing different glacial retreat phases. 

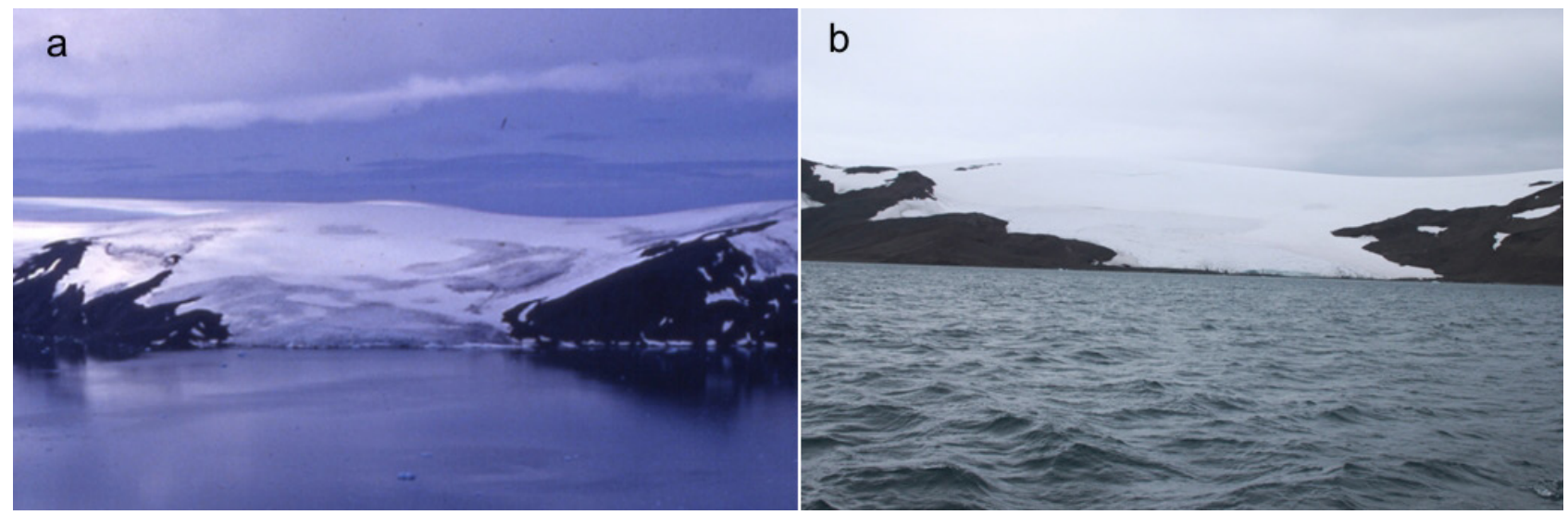

Figure 5. Wanda glacier in 1988 (A) and 2011 (B). Photography in A was provided by Nelson Sambaqui Gruber.

Table 1. Wanda Glacier total area and retreat rates since 1979, was derived from multitemporal satellite images.

\begin{tabular}{cccccc}
\hline \multirow{2}{*}{$\begin{array}{c}\text { Area in } 2011 \\
\left(\mathrm{~km}^{2}\right)\end{array}$} & $2011-2006$ & $2006-2000$ & $2000-1995$ & $1995-1988$ & $1988-1979$ \\
\cline { 2 - 5 } & 0.02 & 0.05 & 0.30 & 0.09 & 0.25 \\
\hline 1.56 & &
\end{tabular}

Over the period 1979 to 2011, glacier retreat amounted to $31 \%$ of the $1.5 \mathrm{~km}^{2}$ total, accounting for an area loss of $0.71 \mathrm{~km}^{2}$. The current continuous and fast retreat phase is attributed to the recent regional warming. There was relatively minor volume change over the period 2000-2011, while over the period 1979-2000 recorded a higher glacier area loss $\left(0.64 \mathrm{~km}^{2}\right)$. In its current phase, Wanda Glacier has presented continuous retreat processes and a thickness reduction, as response to the rapid changing climate in the study area.
Supraglacial ablation and glaciofluvial processes are observed in the Wanda Glacier. As a consequence of these processes and the ice retreat, a large proglacial lagoon was formed (Fig. 6).

Fluting deposits (Fig. 7 and 8), located on the Wanda Glacier proglacial area, on a recently exposed environment, were mapped by high spatial resolution imagery of QUICKBIRD satellite, which indicates that the latest ice flow glacier direction occurred toward northwestern.
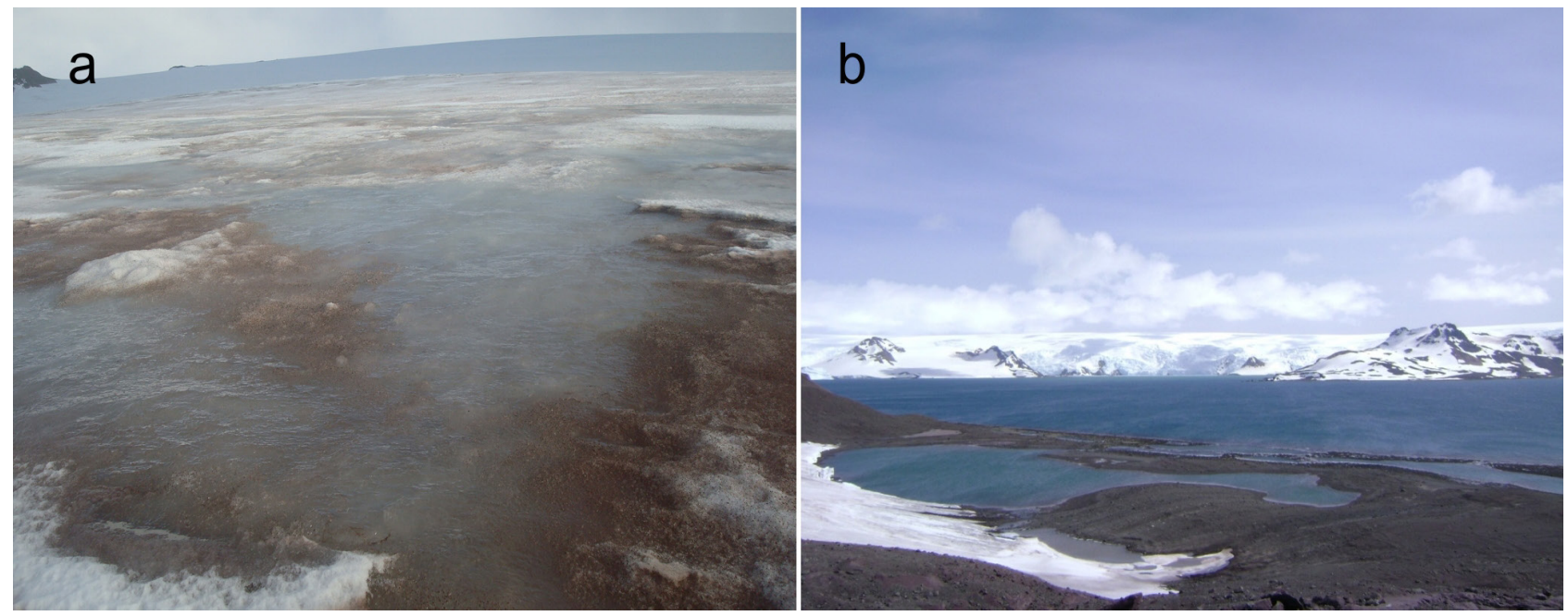

Figure 6. Supraglacial ablation processes (A) and proglacial lagoon (B).

\subsection{Superficial ice flow velocity of the Wanda Glacier}

Maximum ice surface velocity, measured with a stake network, reached $2.2 \mathrm{~cm} \mathrm{~d}^{-1}$ during the period 2007-2011. Considered the velocity data measured by Moll \& Braun (2006), who estimated a mean of $10 \mathrm{~cm} \mathrm{~d}^{-1}$ for glacier during 1995 through
Differential Radar Interferometry (DInSAR), the Wanda Glacier velocity data indicated a decrease ice flow velocity due to reduction in glacier area and thickness. However, higher velocity observed in a sector of this glacier can be explained by ice sliding due to increased topographic gradient (Fig. 9). 


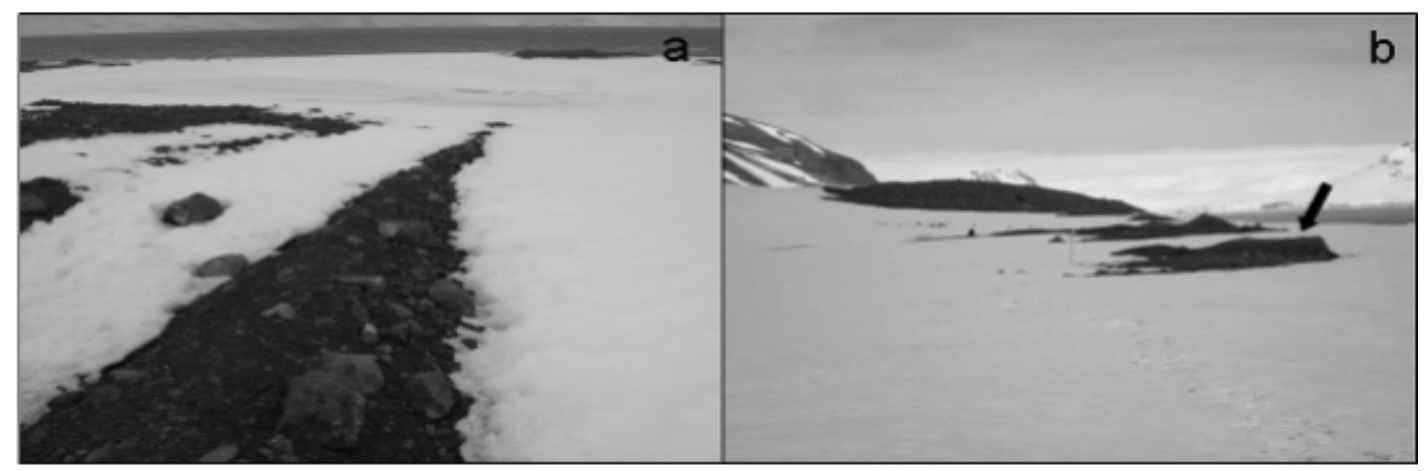

Figure 7. Flutings on the Wanda Glacier proglacial area (B). Photography A shows the glaciofluvial fluting indicated in Figure A.

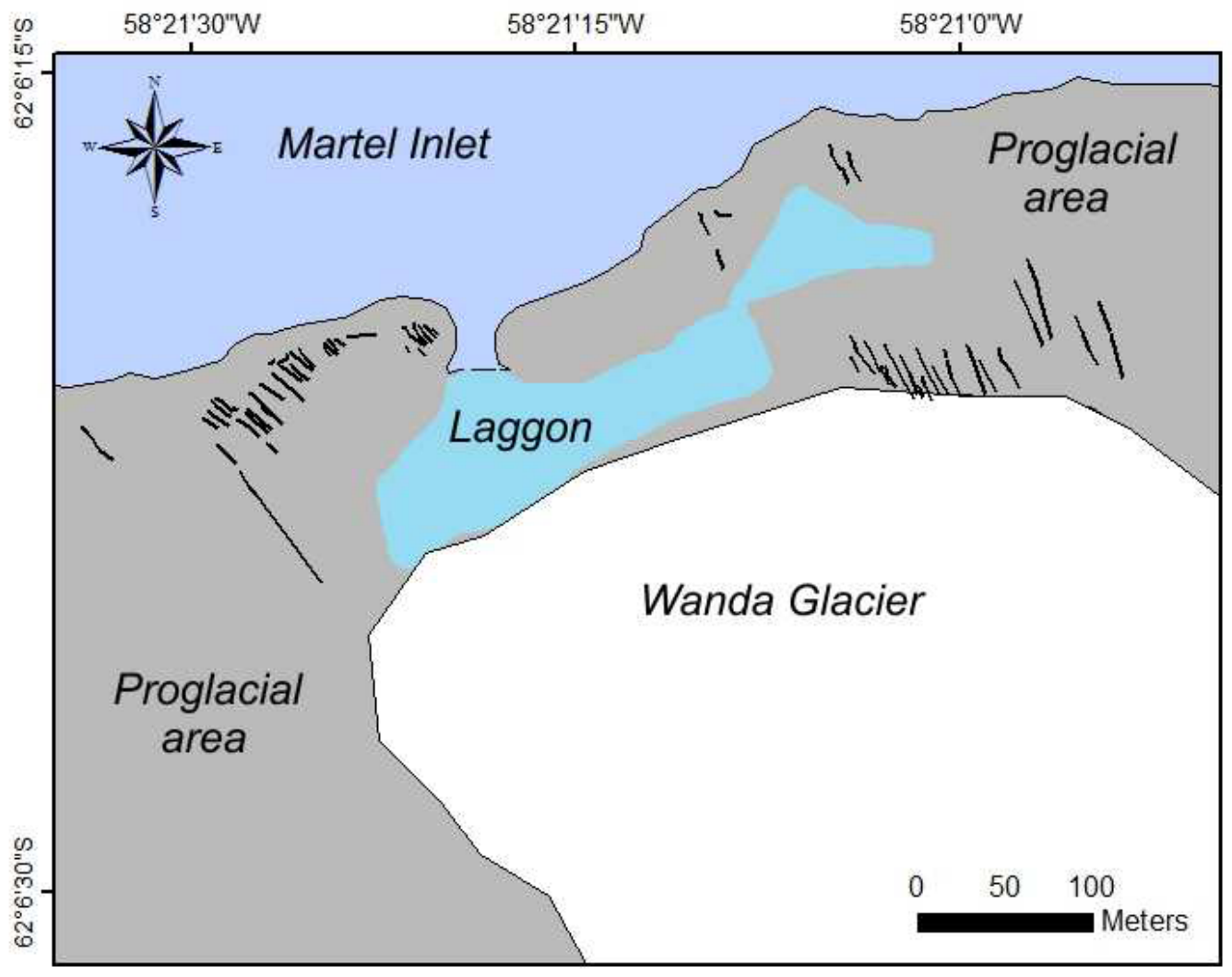

Figure 8. Fluting deposits location on the Wanda Glacier proglacial area, indicating a former northwestern ice flow direction.

\subsection{Digital Elevation Model generation}

Transverse and longitudinal topographic profiles (Fig. 12AB) and a DEM are used to describe the Wanda Glacier surface morphology (Fig. 10 and 11). This elevation model indicated the predominant ice flow direction (Fig. 11) and glacier morphology configuration. The transverse profile (Fig. 12A) showed that surface topography has a great influence in the ice flow. The higher altitudes of the glacier are located at its eastern margin. The longitudinal profile showed a steep slope toward the glacier front (Fig. 9 and 12B).

\section{Discussion}

Results reveal that Wanda Glacier has lost mass over the period 1979-2011. These data are similar to those recently observed at other glaciers in KGI by Arigony-Neto (2001) and Bremer et al. (2004).

The present study reveals that the Wanda Glacier is a small drainage basin and shows higher retreat rate through fusion processes if compared to other glaciers in Martel Inlet. The superficial ablation and the 


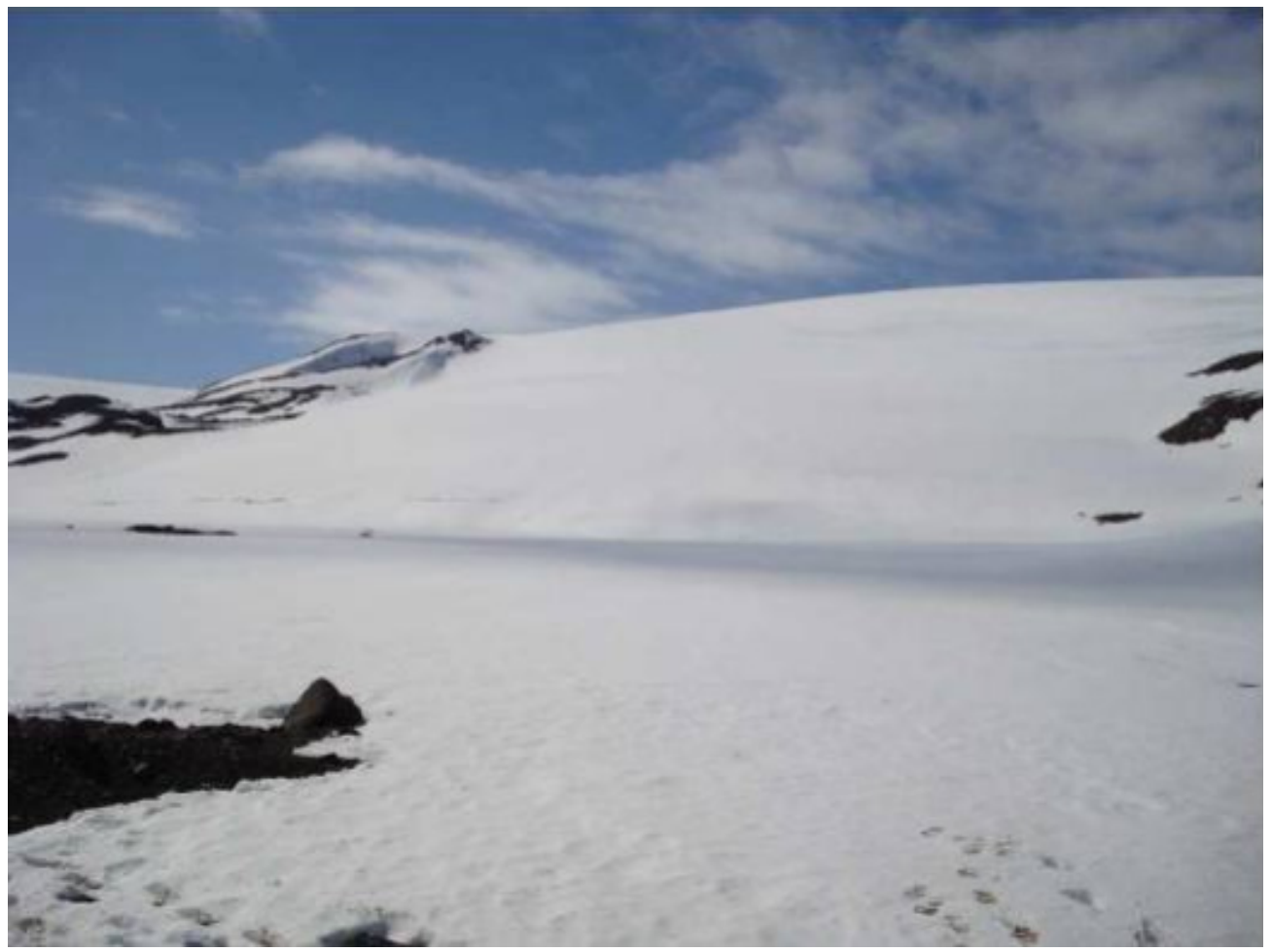

Figure 9. Topographic slope observed on the Wanda glacier ablation area.

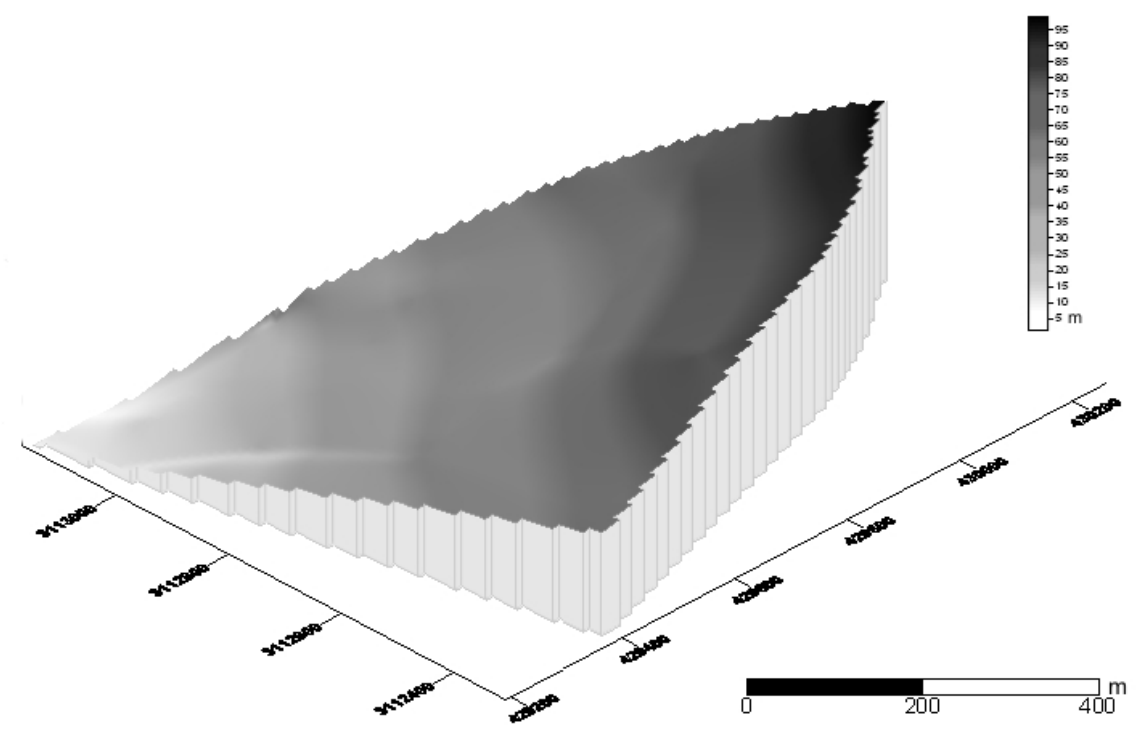

Figure 10. Eastern perspective view of a DEM, showing the Wanda glacier surface morphology.

presence of merging subglacial channels evidenced a temperate basal thermal condition. Topographical data indicate that current glacial dynamic conditions and glacier ice flow patterns are highly influenced by morphometric characteristics of the study area.

The estimated rate of surface movement can be associated with probable basal sliding, which can be caused by subglacial melting processes. According to
Hallet (1979), Riihimaki et al. (2005), and Anderson et al. (2006), there is a link between ice flow velocity processes and the glacial basal sliding. The small ice thickness and drainage basin area can be related with the relative slow ice flow of the glacier.

The glacier retreat rate was pronounced when Wanda Glacier was a tidewater glacier and lost their anchorage point due to the retreat processes and fast 


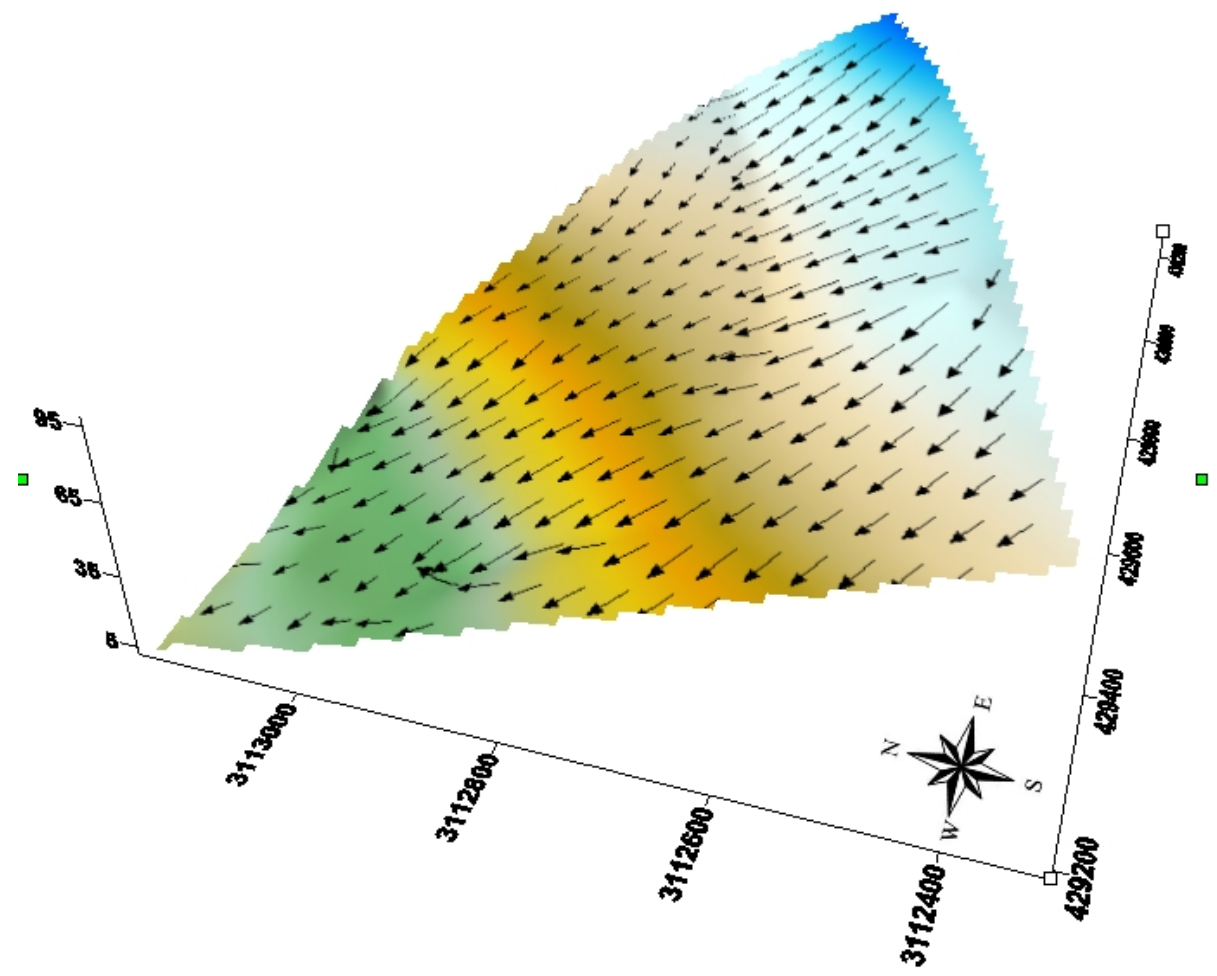

Figure 11. Wanda glacier ice flow direction. Black arrows indicate the ice flow predominant direction, derived from the DEM.
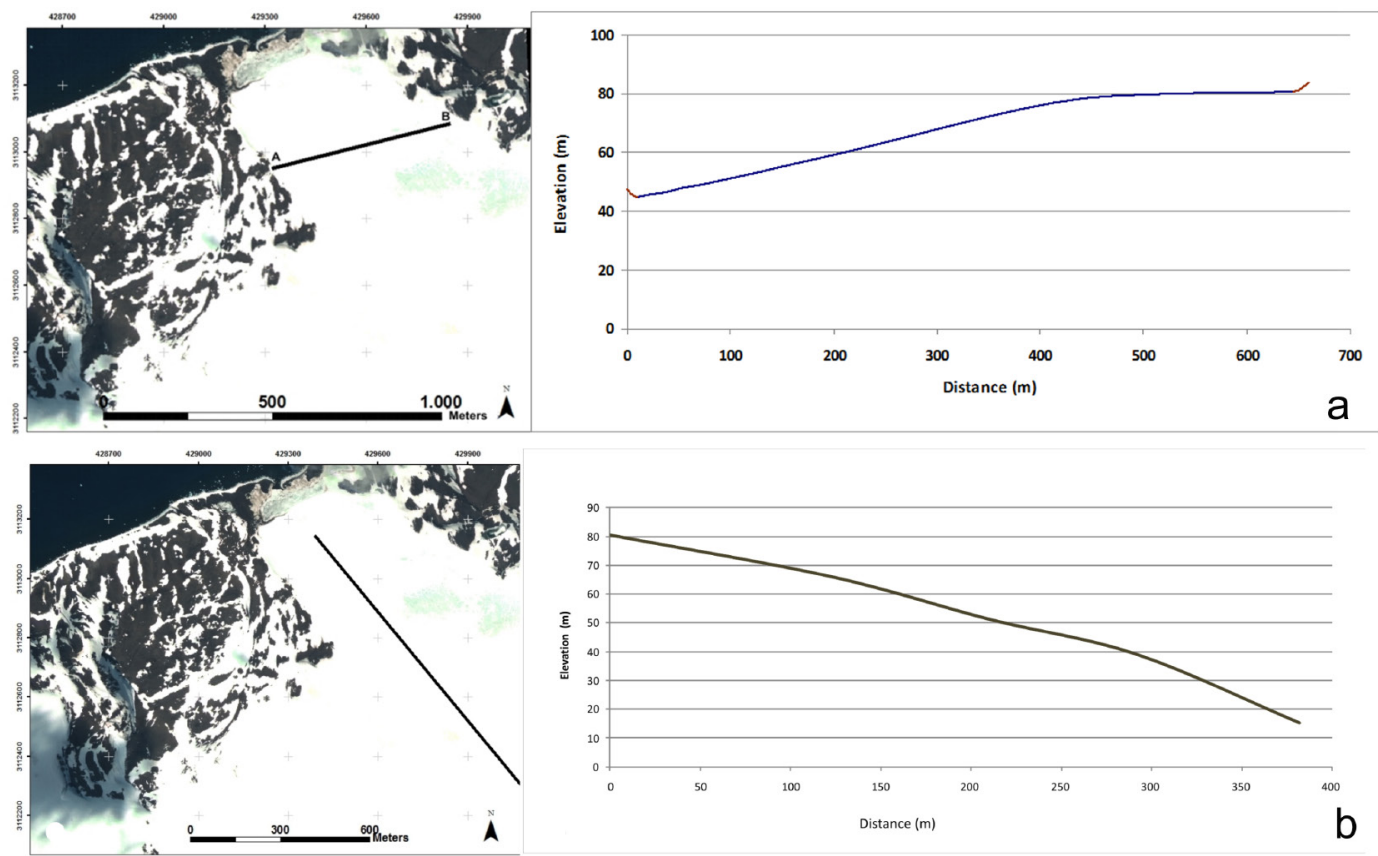

Figure 12. Transverse (A) and longitudinal (B) topographical profile location on Wanda Glacier.

front calving, as evidenced by the reconstruction of former glacier front positions during 1979-1988 period (Fig. 4).

Volumetric data derived from the glacier DEM provided inferences of the ice flow direction and also changes in glacial dynamics. The thinning at the glacier terminus increased the slope on glacier interior portion, as seen in the figs. 9, 10 and 12. Such morphological changes were observed in some Greenland outlet glaciers by Moon \& Jouguin (2008) which could produce a positive feedback, destabilizing the glacier ice front.

\section{Conclusions}

This study provides a comprehensive multitemporal glacier fluctuation record from 1979 to 2011. Wanda Glacier underwent a decrease in area of $0.71 \mathrm{~km}^{2}$ (about $31 \%$ of the $1.5 \mathrm{~km}^{2}$ total surface area) over this period. This glacier inventories 
showed the glacier retreat pattern and provided the basis to compare rates of glacier recession with other glaciers in study area. Maximum ice surface velocity, measured using a stake network, reached $2.2 \mathrm{~cm} \mathrm{~d}^{-1}$ during the period 2007-2011 and transverse profiles show the influence of the subglacial topography on the ice flow. Due to its thermal conditions, small size, a relative slow ice flow and a high retreat rate compared to the other KGI glaciers, Wanda Glacier responds rapidly to climatic variations and is relevant for environmental studies. Multitemporal satellite images, topographic and GPS surveys proved to be useful techniques to monitor glacier changes. Regular continuous monitoring of the Wanda Glacier is important for improving our knowledge of glacier response to climate change.

Acknowledgments - Author thank to the Brazilian National Council for Scientific and Technological Development (CNPq), FAPERGS and Brazilian Antarctic Program (PROANTAR) for financial support for this research. We also thank Peter Barry and Wagner Diniz, José Nelson Barretta, Beatriz Boucinhas and David Henrique, members of the Clube Alpino Paulista (CAP), for logistic support.

\section{References}

Anderson, R.S., Anderson, S.P., Macgregor, K.R., Waddington, E.D., O'neel, S., Riihimaki, C.A. \& Loso, M.G. 2004. Strong feedbacks between hydrology and sliding of a small alpine glacier. Journal Geophysical Research, 109(F1003):1-17.

Anderson, R.S., Molnar, P. \& Kessler, M.A. 2006. Features of glacial valley profiles simply explained. Journal of Geophysical Research, 111(F01004):1-14.

Aquino, F.E. 1999. Sedimentação moderna associada à geleira de maré Lange, ilha Rei George, Antártica. Porto Alegre, 106p. Dissertação de mestrado, Programa de Pós-Graduação em Geologia Marinha. Instituto de Geociências, Universidade Federal do Rio Grande do Sul.

Arigony-Neto, J. 2001. Determinação e interpretação de características glaciológicas e geográficas com sistema de informações geográficas na Área Antártica Especialmente Gerenciada baía do Almirantado, ilha Rei George, Antártica. Porto Alegre,84p. Dissertação de mestrado, Programa de Pós-Graduação em Geologia Marinha. Instituto de Geociências, Universidade Federal do Rio Grande do Sul.

Bennett, M.R. \& Glasser, N.F. 1996. Glacial Geology - Ice Sheets and Landforms. Londres, Wiley \& Sons Ltd, $364 \mathrm{p}$.

Blindow, N., Suckro, S.K., Rückamp, M., Braun, M., Schindler, M., Breuer, B., Saurer, H., Simões, J.C. \& Lange, M.A. 2010. Geometry and thermal regime of the King George Island ice cap, Antarctica, from GPR and GPS.
Annals of Glaciology, 51(55): 103-109.

Braun, M. \& Goßmann, H. 2002. Glacial changes in the area of Admiralty Bay and Potter Cove, King George Island, Antarctica. In: Beyer, M. \& Boelter M. (ed.), GeoEcology of Terrestrial Antarctic Oases, Springer Verlag, p. 75-89.

Braun, M., Saurer, H., Simões, J.C., Vogt, S. \& Goßmann, H. 2001. The influence of largescale atmospheric circulation on surface energy balance and ablation on King George Island, Antarctica. International Journal of Climatology, 21(1): 21-36.

Bremer, U.F. 1998. Morfologia e Bacias de Drenagem da Cobertura de Gelo da ilha Rei George, Antártica. Porto Alegre, 117p. Dissertação de mestrado, Programa de Pós-Graduação em Geologia Marinha. Instituto de Geociências, Universidade Federal do Rio Grande do Sul.

Bremer, U.F, Arigony-Neto, J \& Simões, J.C. 2004. Teledetecção de mudanças nas bacias de drenagem do gelo da ilha Rei George, Shetlands do Sul, Antártica, entre 1956 e 2000 Pesquisa Antártica Brasileira, 4: 37-48.

Cook, A.J., Fox, A.J., Vaughan, D.G. \& Ferrigno, J.G. 2005. Retreating Glacier Fronts on the Antarctic Peninsula over the Past Half-Century. Science, 308: 541-545.

Corseuil, C.W. \& Robaina, A.D. 2003. Determinação altimétrica através do sistema de Posicionamento Global. Revista Ciência Rural, 33(5):673-678.

Ferrando, F.A., Vieira, R. \& Rosa, K.K. 2009. Sobre el calentamiento global en la Isla Rey Jorge: procesos y evidencias en el glaciar Wanda y su entorno. Revista Informaciones Geográficas, 41: 25-40.

Hallet, B. 1979. A theoretical model of glacial abrasion. Journal of Glaciology, 23: 39-50.

Hofmann-Wellenhof, B., Lichtenegger, H. \& Collins, J. 1997. Global positioning system: theory and practice. Wien, Springer-Verlag, 389p.

IPCC. Intergovernmental Panel on Climate Change. 2007. Climate Change 2007: Synthesis Report. Contribution of Working Groups I, II and III to the Fourth Assessment. IPCC, Geneva, Switzerland.

Hope, G., Pask, J., Li, Z., Sun, W. \& Zeng, Q. 1998. Measurements of glacier variation in the Tibetan Plateau using Landsat data. Remote Sensing of Environment, 63: 258-264.

Macgregor, K.R., Riihimaki, C.A. \& Anderson, R.S. 2005. Spatial and temporal evolution of rapid basal sliding on Bench Glacier, Alaska, USA. Journal of Glaciology, 51(172): 49-63.

Macheret Y., Moskalevsky, M., Simões, J.C. \& Ladouch, L. 1997. Radio-echo sounding of King George Island ice cap, South Shetland Islands, Antarctica. Mater Glyatsiol Issled, 83: 121-128.

Moll, A. \& Braun, M., 2006. Determination of glacier velocities on King George Island (Antarctica) by DINSAR. Geoscience and Remote Sensing Symposium, 2006, IGARSS 2006, IEEE International Conference, p. 1236-1239.

Monaghan, A.J., Bromwich, D.H., Chapman, W. \& Comiso, J.C. 2008. Recent variability and trends of Antarctic near-surface temperature. Journal of Geophysical Research, 113(D04105): 1-14. 
Moon, T. \& Joughin, I.J. 2008. Changes in ice front position on Greenland's outlet glaciers from 1992 to 2007. Journal of Geophysical Research, 113(F02022): 1-10.

Park, B.K., Chang, S.K., Yoon, H.I. \& Chung, H. 1998. Recent retreat of ice cliffs, King George Island, South Shetland Islands, Antarctic Peninsula. Annals of Glaciology, 27: 633-635.

Pellikka, P. \& Rees, W. 2010. Remote Sensing of Glaciers. Techniques for topographic, spatial and thematic mapping of glaciers, CRC Press, Taylor \& Francis, A Balkema Book, Leiden, 330 p.

Pfender, M. 1999. Topographie und Glazialhydrologie von King George Island, Antarktis. Münster, 99p. Diplomarbeit im Fach Geophysik, Westfälischen Wilhelms, Universität Münster.

Riihimaki, C.A., Macgregor, K.R., Anderson, R.S., Anderson, S.P. \& Loso, M.G. 2005. Sediment evacuation and glacial erosion rates at a small alpine glacier. Journal of Geophysical Research, Earth Surface, 110(F03003): 1-17.

Rosa, K.K. 2008. Formas e processos dos ambiente de deglaciação das geleiras Wanda e Ecology, Ilha Rei George, Antártica. Porto Alegre, 139p. Dissertação de mestrado, Programa de Pós-Graduação em Geologia Marinha. Instituto de Geociências, Universidade Federal do Rio Grande do Sul.

Rosa, K.K., Vieira, R., Ferrando, F.J. \& Simões, J.C. 2009. Feições sedimentológicas e geomorfológicas do ambiente de deglaciação das geleiras Wanda e Ecology, ilha Rei George. Antártica. Pesquisas em Geociências,

Man 486

Editores: Ulisses Bremmer \& Paulo A. Souza.
37(1): 315-326.

Simões, J.C. \& Bremer, U.F. 1995. Investigations of King George Island ice cover using ERS-1/SAR and SPOT imagery. Revista SELPER, 11(1-2): 56-60.

Simões, J.C., Bremer, U.F., Aquino, F.E. \& Ferron, F.A. 1999. Morphology and variations of glacial drainage basins in King George Island icefield, Antarctica. Annals of Glaciology, 29: 220-224.

Simões, J.S., Ferron, F.A., Bernardo, R.T., Aristarain, A.J., Stiévenard, M., Pourchet, M. \& Delmas, R.J. 2004. Ice core study from the King George Island, South Shetlands, Antarctica. Pesquisa Antártica Brasileira, 4: 9-23.

Simões, J. C., Dani, N., Bremer, U.F., Aquino, F., Arigony-Neto, J. 2004. Small cirque glaciers retreat on Keller Peninsula, Admiralty Bay, King George Island, Antarctica. Pesquisa Antártica Brasileira, Rio de Janeiro, 4: 49-56.

Topcon. 1993. Topcon American Corporation. TOPCON GPS Receivers- GP-R1, GP-R1D, GP-R1DP. Version 7 A: Operating Manual. New Jersey, USA, 219p.

Turner, J., Colwell, S.R., Marshall, G.J., Lachlan-Cope, T.A., Carleton, A.M., Jones, P.D., Lagun, V., Reid, P.A. \& Iagovkina, S. 2005. Antarctic climate change during the last 50 years. Journal of Climatology, 25: 279294.

Vieira, R., Rossato, M.S., Aquino, F.E. \& Simões, J.C. 2005. Feições morfológicas associadas ao ambiente de deglaciação da geleira Ecology, ilha Rei George, Antártica. Revista Brasileira de Geomorfologia, 6(2): 51-60. 